\title{
Isolated Unilateral Temporalis Muscle Hypertrophy: A Case Report and Review of the Literature
} izole Tek Taraflı Temporal Adele Hipertrofisi: Bir Olgu Sunumu ve Literatüre Bakış

\author{
• Ahmet Öğrenci, • Orkun Koban, • Onur Yaman*, • Sedat Dalbayrak \\ Neurospinal Akademi, Clinic of Brain and Neurosurgery, Istanbul, Turkey \\ ${ }^{*}$ Koç University Faculty of Medicine, Department of Brain and Neurological Surgery, istanbul, Turkey
}

\begin{abstract}
Isolated unilateral temporalis muscle hypertrophy is a very rare pathology that nine cases have been reported to date. We report the $10^{\text {th }}$ case of this rare condition and a review of the literature. Swelling of the masticatory muscles may be isolated or may be present together. Reactive and nonreactive causes are accused for the etiology. Significant pathologies accompany non-reactive causes. Some reactive causes are parafunctional jaw habits, excessive gum chewing, and bruxism. Biopsy is the gold standard method of differentiating between reactive and nonreactive causes. The treatment can be tailored according to the biopsy results. Medical treatment, surgery and Botulinum toxin $\mathrm{A}(\mathrm{Bt} \mathrm{A})$ injection are available to treat the reactive causes. BtA therapy is the most effective option. There is no clear information in the literature about the size of swelling in untreated patients. We did not apply an extra treatment after the patient's biopsy except nonsteroidal antiinflammatory drug. The patient is being followed up with no increase in swelling.
\end{abstract}

Keywords: Hypertrophy, masticatory, swelling, temporalis muscle
İzole unilateral temporal kas hipertrofisi nadir görülen bir patolojidir ki şu ana kadar dokuz olgu yayınlanmıştır. Biz bu nadir durumla alakalı 10. olguyu sunup literatüre göz atacağız. Çığneme kaslarındaki şişlikler izole olabildiği kadar bazı kas gruplarıyla beraber de prezente olabilirler. Etiyolojide reaktif ve nonreaktif nedenler suçlanmaktadır. Nonreaktif nedenlere bakıldığında önemli patolojilerin eşlik etmesi görülür. Reaktif nedenlerde ise parafonksiyonel çene hareketleri, sakız çiğneme alışkanlıkları, bruksizm (diş gıırdatma) vardır. Biyopsi reaktif ve nonreaktif nedenleri ayırmada altın standart metoddur. Biyopsi sonucuna göre tedavi şekillenebilir. Reaktif nedenleri tedavi etmede medikal tedavi, cerrahi tedavi ve botoks tedavisi mevcuttur. En etkilisi botoks tedavisidir. Tedavi edilmeden takip edilen hastalardaki şişlik boyutu ile ilgili literatürde net bilgi yoktur. Biz hastamıza biyopsi sonrası nonsteroid antienflamatuvar ajan kullanımı dışında ekstra bir tedavi uygulamadık. Şu an takipleri devam etmekte ve şişliğin boyutu artmamaktadır.

Anahtar Sözcükler: Hipertrofi, çiğneme, şişlik, temporal adele

\section{Introduction}

The management of temporalis muscle hypertrophy depends on its origin. It is necessary to differentiate between reactive and non-reactive hypertrophy. The process is known in case of reactive hypertrophy. In nonreactive hypertrophy, it is necessary to investigate the cause. Up to now, there have been nine reported cases of isolated unilateral temporalis muscle hypertrophy (IUTMH) in the literature. Here, we present a case of IUTMH and a review of the literature.

\section{Case}

A 35-year-old female patient was admitted to our clinic with painless swelling in the right temporal region (Figure 1). The patient had no complaints other than cosmetic concerns. She had no chronic disease. The swelling started three months ago and has been stable for the last one month.

There was no asymmetry on the face of the patient. There was no skin abnormality. There was no findings
Address for Correspondence/Yazışma Adresi: Ahmet Öğrenci Neurospinal Akademi, Clinic of Brain and Neurosurgery, İstanbul, Turkey Phone: +90 5068860451 E-mail: drahmetogrenci@gmail.com ORCID ID: orcid.org/0000-0002-7580-0227 Received/Geliş Tarihi: 10 May 2017 Accepted/Kabul Tarihi: 13 November 2017
Copyright 2018 by The Medical Bulletin of University of Health Sciences Haseki Training and Research Hospital
The Medical Bulletin of Haseki published by Galenos Yayinevi.

๑Telif Hakkı 2018 Sağlık Bilimleri Üniversitesi Haseki Eğitim ve Araştırma Hastanesi Haseki Tıp Bülteni, Galenos Yayınevi tarafından basıımıştır. 
in oral, dental and jaw joint (temporomandibular: TM) examination. There was no other complaint. The patient had no bruxism and there was no history of trauma. During this time, she had used anti-inflammatory drugs but the swelling has increased. Routine blood tests were all within the normal limits. Contrast-enhanced cranial magnetic resonance imaging showed a non-contrasting muscle structure which appeared isointense with normal muscle. (Figure 2, 3) The right temporal muscle was clearly hypertrophic with respect to the left. There was no intracranial pathology.

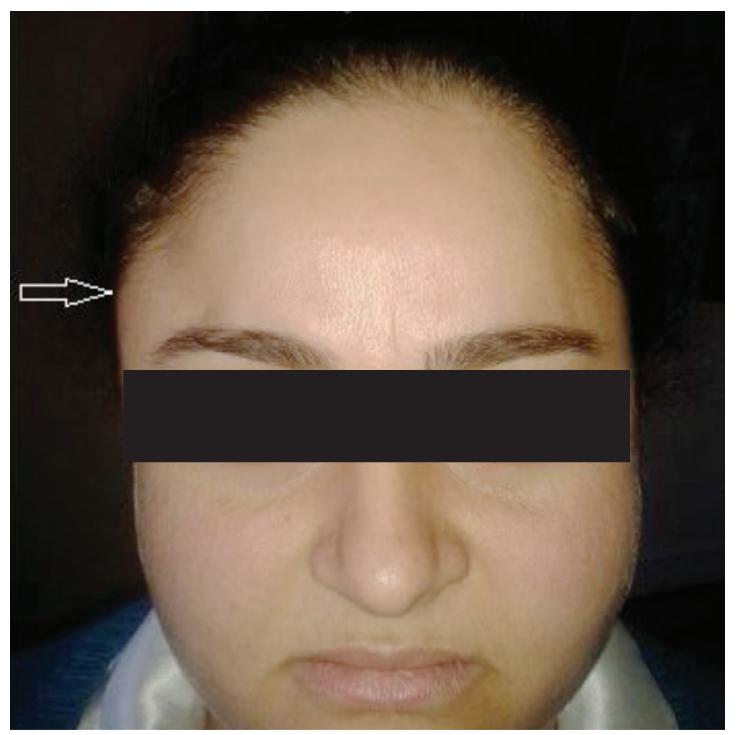

Figure 1. Frontal view of the patient. Right swelling of temporal region is seen

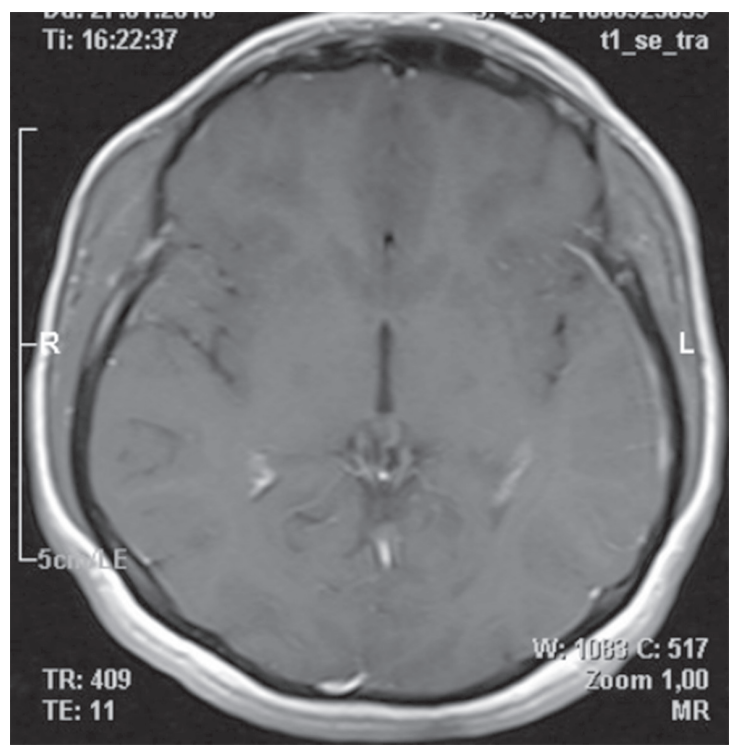

Figure 2. Axial image of cranial magnetic resonance imaging. Right temporal muscle intensity is similar to left side.Contrast enhancement is not seen
The other masticatory muscles groups were symmetric. There were no bone pathology on cranial computed tomography and x-ray images. TM joint appeared normal. The patient underwent biopsy for diagnostic purposes. A biopsy was performed under local anesthesia with a small incision and the result was reported as normal muscle tissue (Figure 4).

The patient refused Botulinum toxin $\mathrm{A}(\mathrm{BtA})$ treatment that we recommended after biopsy. Now the patient is in the $3^{\text {rd }}$ year and there is no increase in the muscle mass.

To our knowledge, this is the first case of isolated unilateral temporal hypertrophy reported in Turkey.

The permission has been got from the patient for the article.

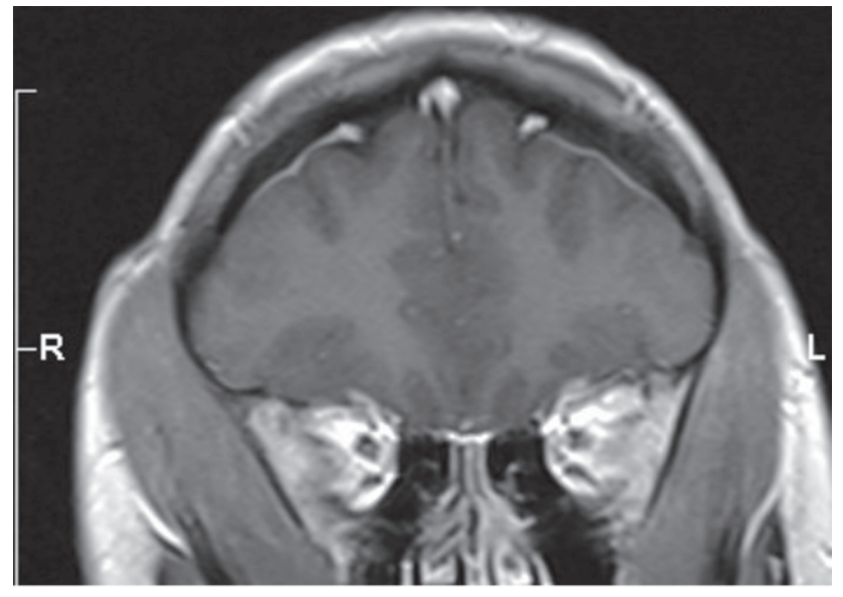

Figure 3. Coronal image of cranial magnetic resonance imaging. Right temporal muscle intensity is similar to left side. Contrast enhancement is not seen

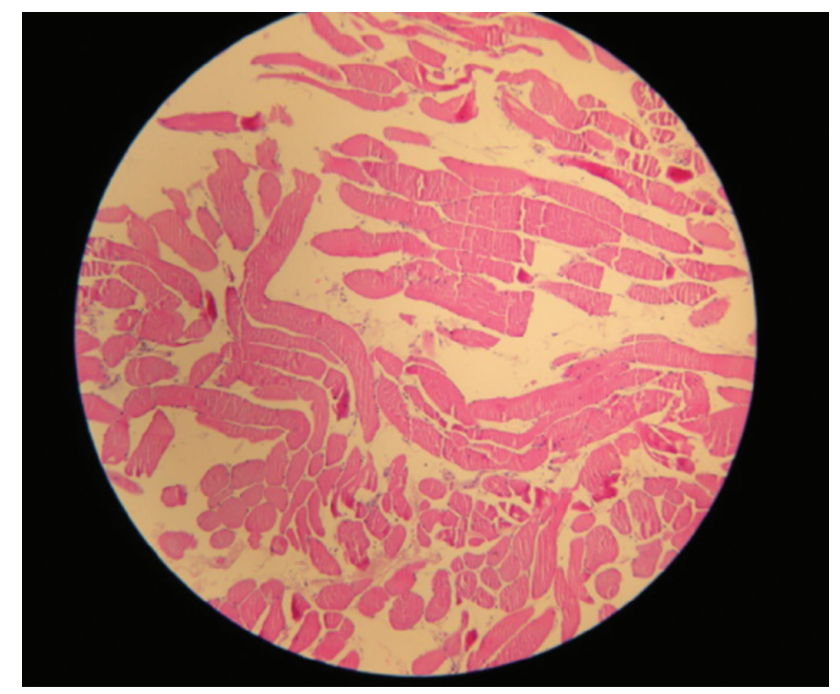

Figure 4. The biopsy result was as normal muscle tissue (hematoxylin \& eosin X10) 
Öğrenci et al. Temporalis Muscle Hypertrophy

\begin{tabular}{|c|c|c|c|c|c|}
\hline Author & Year & Age & Gender & Presentation & Treatment \\
\hline Wilson and Brown (5) & 1990 & 43 & $\mathrm{~F}$ & Painless swelling & Supportive \\
\hline Serrat et al. (9) & 1998 & 15 & $\mathrm{~F}$ & Swelling & Symptomatic \\
\hline Isaac (14) & 2000 & 35 & M & Painless swelling & Botox A \\
\hline Lowry and Helling (4) & 2003 & 45 & M & Swelling & Symptomatic \\
\hline Prantl et al. ${ }^{*}(10)$ & 2005 & 48 & $\mathrm{~F}$ & Painless swelling & Surgery \\
\hline Vordenbäumen et al. (12) & 2009 & 22 & $\mathrm{~F}$ & Painful swelling, headaches & Acetaminophen \\
\hline Wang et al. (8) & 2013 & 17 & M & - & Botox A \\
\hline Katsetos et al. (7) & 2014 & 62 & M & - & Botox A \\
\hline Present case & - & 35 & $\mathrm{~F}$ & Painless swelling & NSAI-follow up \\
\hline
\end{tabular}

\section{Discussion}

The first case of masticatory muscle hypertrophy was reported by Legg (1) in 1880.

Masticatory muscle hypertrophy may affect the masseters, temporalis and pterygoid muscles and is usually bilateral (2-4).

Unilateral appearance is usually less common. IUTMH was published long after the report of masticatory muscle hypertrophy. The first report of IUTMH was published by Wilson and Brown (5) in 1990.

To the best of our knowledge since then, nine cases have been reported (Table 1). The case presented here is the $10^{\text {th }}$ in the world and the first in Turkey.

Painful or painless swelling and headache are generally the first presentation complaints. No apparent side dominance has been reported in the literature.

The etiology is not clear, however, both reactive and nonreactive causes are accused of causing. Nonreactive causes include genetic problems, myopathies, inflammatory or infectious causes, vascular malformations, myositis, neoplastic processes, and metastases $(4,6-8)$.

Hypertrophy of the temporal region may be seen in bone deformities after craniofacial trauma, in those who have joint problems and dental problems.

Regarding the reactive causes, patients with parafunctional jaw habits, excessive gum chewing habits, and bruxism are at risk. Oral-dental examination should be performed. Dental wear may be help to diagnose bruxism. It is also stated that psychogenic disorders can be the trigger if there is no cause (6). However, there is no exact etiology identified. As a matter of fact, we could not find any reason in our patient.

Our patient had no parafunctional habits. We could not detect any abnormality in the physical examination, radiological evaluation and laboratory tests.
The diagnosis is confirmed by biopsy $(4,7-9)$. Biopsy is a quick, simple and low-risk procedure for identifying reactive or nonreactive causes. No matter how many radiological or laboratory tests are performed, they will not replace the data that the biopsy will yield. Biopsy is required in all patients with temporalis muscle hypertrophy.

Katsetos et al. (7) and Harriman (6) investigated histochemistry of mascitory muscle hypertrophy and have argued that the dominance of type 1 myofibrils was the cause. Katsetos et al. (7) stated that the diameter of type 1 fibers was larger than that of type 2 fibers, and there was not myopathic view on pathological examination.

After diagnosis, treatment should be planned according to the etiology. If it is related with nonreactive processes, the primary reason should be treated. However, for a reactive cause, when the biopsy reveals normal muscle tissue, the treatment may vary. If the patient has behaviors that may cause hypertrophy in this area, it can be suggested to reduce them and patient can be followed up. Psychological reasons should be treated; it will be difficult to achieve success with other therapies without treating psychological causes. Analgesics, nonsteroidal anti-inflammatory (NSAI) drugs, acetaminophen, or muscle-relaxant drugs can be used (7). BtA therapy can be performed in the next period or muscle excision can be done as a more invasive treatment option (10). Surgical management is considered in patients not benefiting from other methods, but it should not be the first treatment option. Trismus, fibrosis, hematoma and recurrence may develop after surgery (10-12). BtA injection is a more rational treatment option at this point. Although BtA is more costly than the other treatments, it causes paralysis in the muscle structure, reduces tonus, and causes atrophy and decrease in headache (13). Periodic BtA injections may be required (8). In botulinum toxin treatment BtA is recommended due to the duration of influence (14). Botulinum $\mathrm{F}$ has shorter effect compared to BtA. 
In our case, we ordered NSAl based on the biopsy result. We recommended BtA treatment since the patient did not benefit from medical agents, however, the patient refused the treatment. Thus, we follow up the patients with the size of mass. No progression or regression was observed during the $3^{\text {rd }}$ year of follow-up.

We assume that temporal hypertrophy may continue to a certain point and then may remain stable. In our theory, the increased pressure in the temporal region prevents growth in muscle mass. Therefore, patients with temporal hypertrophy can be followed up after biopsy if there are no serious symptoms.

IUTMH is very rare cause of swelling of the temporal region. If there is not a non reactive cause, it is a reactive hypertrophy. Radiographic images show normal results or normal intensity of the other muscles. In the differential diagnosis, biopsy should be performed. Various treatments, especially Botulinum toxin, can be ordered after biopsy, or the patient can be followed up if there is no evidence of an increase in the size of the mass, and there is no serious symptom.

\section{Authorship Contributions}

Surgical and Medical Practices: A.Ö., O.K. Concept: A.Ö., O.K. Design: A.Ö., O.Y. Data Collection or Processing: A.Ö., O.K. Analysis or Interpretation: A.Ö., O.K., O.Y., S.D. Literature Search: A.Ö., O.Y. Writing: A.Ö.

Conflict of Interest: No conflict of interest was declared by the authors.

Financial Disclosure: The authors declared that this study received no financial support.

\section{References}

1. Legg JW. Enlargement of the temporal and masseter muscles on both sides. Trans Pathol Soc Lond 1880;31:361-6.

2. Kessel LJ. Benign bilateral masseteric hypertrophy with temporal muscle involvement. Oral Surg Oral Med Oral Pathol 1970;30:450-3.
3. Kitagawa $Y$, Hashimoto $K$, Kuriyama M. Hypertrophic branchial myopathy with uniform predominance of type 1 fibres. Case report. Scand J Plast Reconstr Surg Hand Surg 2000;34:391-6.

4. Lowry TR, Helling E. Unilateral temporal muscle hypertrophy: a rare clinical entity. Ear Nose Throat J 2003;82:198-9.

5. Wilson PS, Brown AM. Unilateral temporalis muscle hypertrophy: case report. Int J Oral Maxillofac Surg 1990;19:287-8.

6. Harriman DG. The histochemistry of reactive masticatory muscle hypertrophy. Muscle Nerve 1996;19:1447-56.

7. Katsetos CD, Bianchi MA, Jaffery $F$, Koutzaki S, Zarella M, Slater R. Painful unilateral temporalis muscle enlargement: reactive masticatory muscle hypertrophy. Head Neck Pathol 2014;8:187-93.

8. Wang BH, Moon SJ, Wang H, Olivero WC. Isolated unilateral temporalis muscle hypertrophy. J Neurosurg Pediatr 2013;11:451-3.

9. Serrat A, García-Cantera JM, Redondo LM. Isolated unilateraltemporalis muscle hypertrophy. A case report. Int J Oral Maxillofac Surg 1998;27:92-3.

10. Prantl L, Heine N, Ulrich D, Eisenmann-Klein M. Recurrence of isolated unilateral temporalis muscle hypertrophy: case report. Aesthetic Plast Surg 2005;29:574-5.

12. Vordenbäumen S, Groiss SJ, Dihné M. Isolated unilateral temporal muscle hypertrophy: a rare cause of hemicranial headache. Headache 2009;49:779-82.

13. Mandel L, Tharakan M. Treatment of unilateral masseteric hypertrophy with botulinum toxin: case report. J Oral Maxillofac Surg 1999;57:1017-9.

14. Isaac AM. Unilateral temporalis muscle hypertrophy managed with botulinum toxin type $\mathrm{A}$. Br J Oral Maxillofac Surg 2000;38:571-2. 